\title{
Pterion Formation in North Indian Population: An Anatomico-Clinical Study
}

\author{
Formación del Pterion en una Población del Norte de India: Un Estudio Anátomo-Clínico
}

\author{
Seema* \& Anupama Mahajan**
}

SEEMA \& MAHAJAN, A. Pterion formation in North Indian population: an anatomico-clinical study. Int. J. Morphol., 32(4):14441448, 2014.

SUMMARY: Pterion is a point of sutural confluence seen in the norma lateralis where frontal, parietal, temporal and sphenoid bones meet. This craniometric point is related to various structures in the cranial cavity like middle meningeal artery, anterior pole of insula and Broca's area. This study was done to find most common variation in its shape and presence of epipteric bones and to compare with other racial groups from previous study. Fifty adult human skulls of unknown sex taken from Department of Anatomy, Sri Guru Ram Das Institute of Medical Sciences and Rsearch, Vallah (Amritsar, India) were examined on both sides for the type and position of the pterion. Four types of pterion formation were noted. Sphenoparietal was observed in $89 \%$, frontotemporal in $7 \%$, stellate in $4 \%$ and epipteric in $12 \%$ of cases. The pterion was found to be $3.1 \pm 0.44 \mathrm{~cm}$ on the right side, $3.4 \pm 0.40 \mathrm{~cm}$ on the left side from the frontozygomatic suture and $4.1 \pm 0.45 \mathrm{~cm}$ on the right side and $4.4 \pm 0.32 \mathrm{~cm}$ on the left side from the centre of zygoma. These variations in the sutural morphology is comparable to other population. Its position is of interest to anthropologists, forensic pathologists and surgeons who deserve further investigation in population of different area.

KEY WORDS: Pterion; Sphenoid; Craniometric; Sutural.

\section{INTRODUCTION}

Pterion is an important neurosurgical and anthropological landmark in the temporal fossa where facial skeleton, calvaria and skull base meet (Urzi et al., 2003). Temporal fossa has an irregular H-shaped suture where the frontal, parietal, greater wing of sphenoid and squamous part of the temporal bone meet. (Williams et al., 2008). Horizontal limb is between the anteroinferior parietal angle and apical border of greater wing of sphenoid (Moore \& Dalley, 1992). Pterion is an important guide for age and sex determination as well as archaeological and forensic estimation (Lovejoy et al., 1985). It is also an important site to assess anterior branch of middle meningeal artery, Broca's area, sphenoid ridge and optic canal (Saxena et al., 2003). Initially pterion was classified into three types by Broca (1875). They were sphenoparital, frontotemporal and stellate. Later on four types were given by Murphy (1956) as sphenoparital, frontotemporal, stellate and epipteric types. The sphenoparietal type of sutural pattern occurs in which the sphenoid and parietal bone articulate directly. The frontotemporal type is one in which frontal and temporal bones are in direct contact. The stellate type has frontal, parietal, temporal and sphenoid bones articulaye at a sin- gle point. The epipteric type means the presence of the sutural bones at the pterion. Wang et al. (2006), further elaborated and gave the six types. He gave additional zygomaticoparital type, a variation of the sphenoparietal type in which zygomatic bone articulates with the parietal bone separating the frontal bone from the temporal or sphenoid bone and zygomaticotemporal type in which the zygomatic bone articulates with the temporal bone separating the sphenoid from frontal and parietal bones. It is considered as the subtype of frontotemporal type. The most common type as well as the position of the ptrion varies in different populations (Morales et al. 2011). Pterional fracture can tear frontal branch of middle meningeal artery leading to extradural hematoma (Lama \& Mottolese, 2000). The anatomical location of the pterion helps in surgical interventions following extradural hemorrhage as well as tumor involving the inferior aspect of frontal lobe such as olfactory meningeomas (Specktor et al., 2005). It is also helpful in operations involving Brocas motor speech area (Lindsay et al., 1991) in repairing the aneurysms of middle meningeal artery amd upper basilar complex (Escosa-Bagé $e t$ al., 2002).

\footnotetext{
* Professor, Department of Anatomy, Sri Guru Ram Das Institute of Medical Sciences and Research, Vallah, India.

*** Professor and Head, Department of Anatomy, Sri Guru Ram Das Institute of Medical Sciences and Research, Vallah, India.
} 


\section{MATERIAL AND METHOD}

Fifty adult human skulls of unknown sex were taken from Department of Anatomy, Sri Guru Ram Das Institute of Medical Sciences and Research, Vallah. On both sides of each skull sutural pattern of pterion was determined (Murphy). Centre of pterion was determined by finding the lips of contact between the parietal and sphenoid bone in sphenoparietal type and between the frontal amd squamous temporal in frontotemporal type. Measurements were taken on both sides from the centre of pterion to midpoint of zygoma (ZY) to frontozygomatic suture (FZ) (Fig. 1) using digital vernier calipers with an accuracy of $0.001 \mathrm{~mm}$ (trade mark and manufacturer was Yamayo). Each measurement was taken on consective two days at the same time to measure the technical error of measurement (TEM), relative technical error of measurement (rTEM) and coefficient of reliability $(\mathrm{R})$.

\section{RESULTS}

Four types of pterion were observed (Table I). They were sphenoparietal (89\%) (Fig. 2A), frontotemporal (7\%) (Fig. 2B), stellate (4\%) (Fig. 2C) and epipteric (12\%) (Fig. 2D). Data was

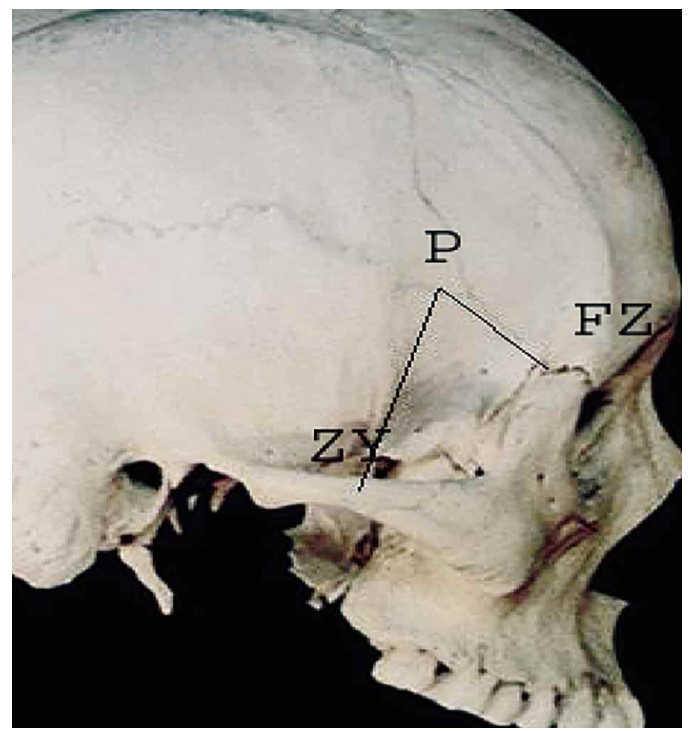

Fig. 1. Dimensions taken for location of the pterion. $\mathrm{P}=$ Center of pterion, $\mathrm{FZ}=$ Frontozygomatic suture, $\mathrm{ZY}=$ Center of the zygoma.

Table I. Frequency and distribution of types of pterion.

\begin{tabular}{lccc}
\hline Type of pterion & Frequency (\%) & Right side (50) & Left side (50) \\
\hline Sphenopatrietal & 89 & 44 & 45 \\
Frontotemporal & 7 & 4 & 3 \\
Stellate & 4 & 2 & 2 \\
Epipteric & 12 & 6 & 6
\end{tabular}

compared with the other populations (Table II). The mean amd standard deviation of various linear measurements taken from the center of pterion using SPSS 16 programme of Windows were shown in Table III. The degree of measurement error in the present study showed a high degree of precision (TEM $<1 \mathrm{~mm}, \mathrm{eTEM}<1 \%, \mathrm{R}>0.95)$.

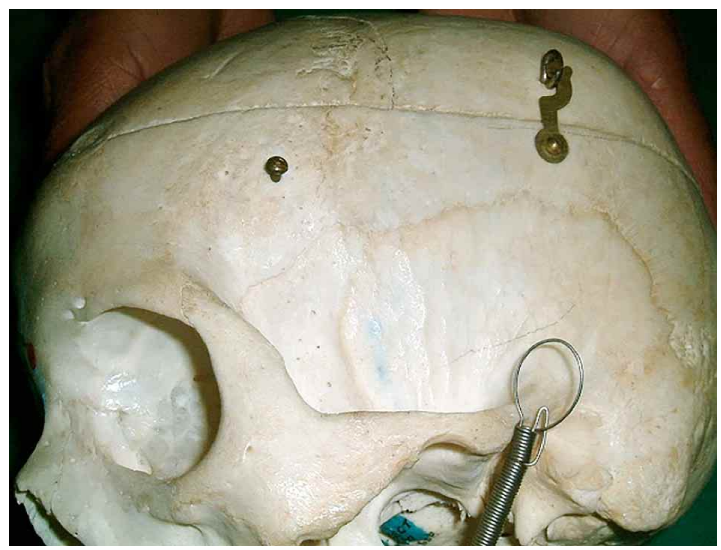

Fig. 2. Sphenoparietal variety.

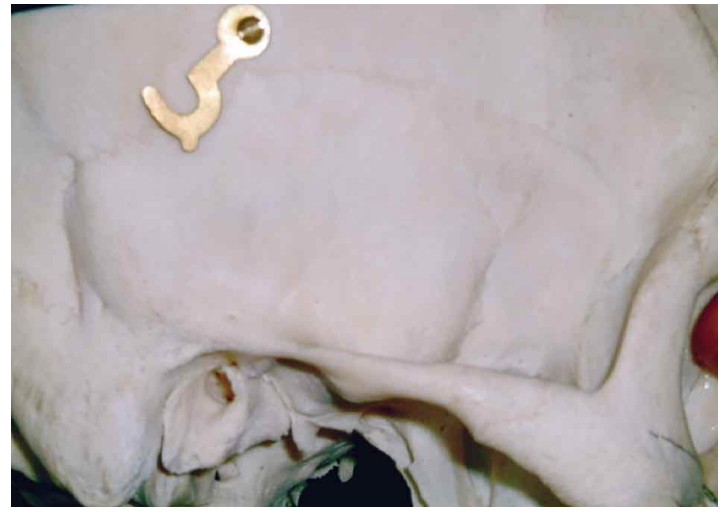

Fig. 3. Frontotemporal variety.

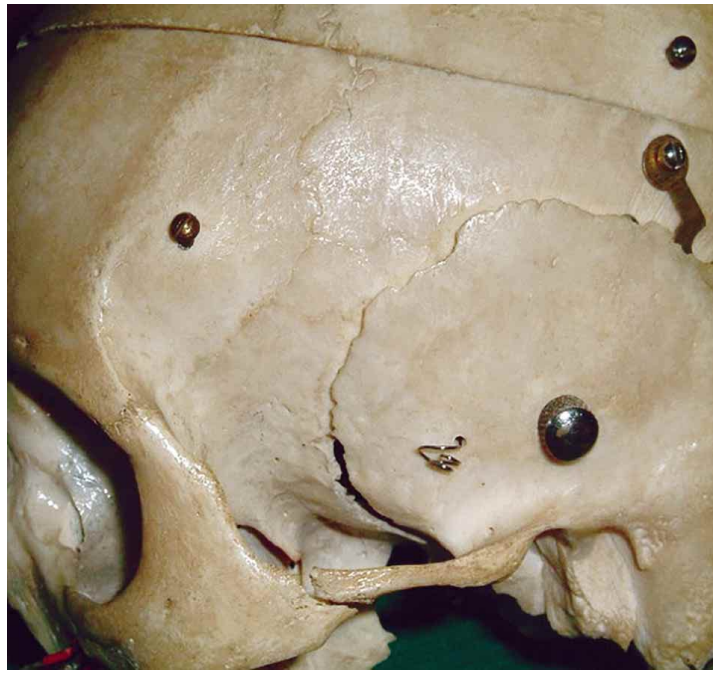

Fig. 4. Epipteric variety. 
Table II. Comparison of different studies.

\begin{tabular}{|c|c|c|c|c|c|c|}
\hline Author & Population & Number & Sphenoparietal & Frontotemporal & Epipteric & Stellate \\
\hline Murphy (1956) & Australian Aborigines & 388 & 73 & 7.5 & 18.5 & --- \\
\hline Ahuja et al. (1971) & Indians & --- & 95.24 & 2.84 & 18.5 & 1.9 \\
\hline Aggarwal et al. (1980) & North Indians & 900 & 93.48 & 4.35 & 23.34 & 2.17 \\
\hline Matsumara et al. (1991) & Japanese & 614 & 79.1 & 2.6 & 17.7 & 0.6 \\
\hline Ersoy et al. (2003) & Turks & 300 & 87.35 & 3.47 & 8.98 & 0.2 \\
\hline Saxena et al. (2003) & Indians & 203 & 84.72 & 10.01 & --- & 5.17 \\
\hline Oguz et al. (2004) & Turkish & 26 & 88 & 10 & 2 & --- \\
\hline Mwachaka et al. (2009) & Kenyans & 79 & 66 & 15 & 12 & 7 \\
\hline Natekar et al. (2010) & Indians & 150 & 85.33 & 8 & 51.4 & 10.6 \\
\hline Zalawadia et al. (2010) & Gujurat & 42 & 91.7 & 2.4 & 4.8 & 1.2 \\
\hline Present study (2014) & North Indians & 50 & 89 & 7 & 10 & 4 \\
\hline
\end{tabular}

Table III. Comparison of pterion position.

\begin{tabular}{|c|c|c|c|c|}
\hline \multirow[t]{2}{*}{ Author } & \multicolumn{2}{|c|}{$\begin{array}{c}\text { Center of pterion to frontozygomatic } \\
\text { suture }(\mathbf{c m})\end{array}$} & \multicolumn{2}{|c|}{$\begin{array}{c}\text { Center of pterion to the center of } \\
\text { zygomatic } \operatorname{arch}(\mathrm{cm})\end{array}$} \\
\hline & Right side & Left side & Right side & Left side \\
\hline Ahuja et al. (1971) & 2.70 & 2.80 & 3.50 & 3.50 \\
\hline Zalawa dia et al. (2010) & $3.73 \pm 0.5$ & $3.55 \pm 0.44$ & $3.12 \pm 0.44$ & $2.97 \pm 0.33$ \\
\hline Present study (2014) & $3.1 \pm 0.44$ & $3.4 \pm 0.40$ & $4.1 \pm 0.45$ & $4.4 \pm 0.32$ \\
\hline
\end{tabular}

\section{DISCUSSION}

Pterion presents the site of anterolateral fomtenella of neonatal skull which closes at the third month after birth (Williams et al.). It is an important anatomical landmark situated $4 \mathrm{~cm}$ superior the midpoint of the zygomatic arch amd $2.5 \mathrm{~cm}$ posterior the frontozygomatic suture. In neurosurgery, minimally invasive bony aperture is required where neuronavigation devices are not available (Ersoy et al., 2003; Oguz et al., 2004; Singh et al., 2012). One or more pterion ossicles or epipteric bones may appear at this site. They are in great number in hydrocephalic skulls and represent rapid cranial expansion (Natekar et al., 2011). It can complicate the surgical intervention causing pitfalls. In the present study four types of pterion were noted. They were sphenoparietal in $89 \%$ of cases, frontotemporal in $7 \%$ of cases, stellate in $7 \%$ cases and epipteric in $12 \%$ of cases. Sphenoparietal type is most common type in the present study as in Asiatic Indians (95.1\%) (Saxena et al., 1988), North Indians (87.72\%) Saxena, 2003), South Indians (93.55) (Manjunath \& Thomas, 1993) and Nigerians $(87.79 \%)$ (Saxena et al., 1988), 93.48\% in North Indians (Agarwal et al., 1980) but is low in Koreans (76.5\%) (Lee et al., 2001) and Kenyans (66\%) (Mwachaka et al, 2009). The present study showed $7 \%$ incidence of frontotemporal variety which is lower than Nigerians (10.11-23.6\%) (Saxena et al., 1988), Kenyans (Mwachaka et al.) and Papuan (41.4\%) (AshleyMontagu, 1933) but comparable to Agarwal et al. (4.35\%). Epipteric bones were found in $12 \%$ of skulls in which it was bilateral in 4 skulls, only on left side in 2 skulls, on the right side in 2 skulls. The incidence was more in Nigerians (23.6\%) (Saxena et al., 1988), Australians (18.5\%) (Murphy) but was comparable to Saxena et al., (2003) (10.01\%) and was less than Agarwal et al. (23.34\%) done in same North Indian population. The phylogenetic theory of formation of different types of pterion was given by Ahuja et al. (1971). According to this theory, the frontotemporal type of pterion was common in primates and sphenoparietal type was common in human beings. The anterosuperior segment of the squamous part of the temporal bone of the primates may have detached from the parent bone and got incorporated in the posterosuperior angle of the greater wing of sphenoid during phylogenesis thus changing the pattern from frontotemporal to sphenoparietal type of the pterion. If however the desquestrated portion remained permanantly detached from both of the bones it becomes the epipteric type.

The most predominent type of pterion in North Indian population was sphenoparietal type. The knowledge of the type and mean position of the pterion in relation to various landmarks will be important in surgical interventions involving the burr hole surgeries. The detailed knowledge of position of this important landmark in North Indians that will help the surgeons for operation planning and succss of surgery in relation to this anatomic variable topographic cranial point. 
SEEMA \& MAHAJAN, A. Formación del pterion en una población del norte de India, un estudio anátomo-clínico. Int. J. Morphol., 32(4):1444-1448, 2014.

RESUMEN: El pterion es un punto correspondiente con el extremo posterior de la sutura donde se ubican los huesos frontal, parietal, temporal y esfenoides. Este punto métrico del cráneo se relaciona con diversas estructuras en la cavidad craneal como la arteria meníngea media y polo anterior de la ínsula en el área de Broca. Este estudio se realizó para determinar la variación más común de la forma y presencia de huesos epiptéricos y comparar estos con otros grupos raciales. Cincuenta cráneos humanos adultos de sexo desconocido obtenidos en el departamento de anatomía, Sri Guru Ram Das Instituto de Ciencias Médicas e Investigaciones, Vallah (Amritsar, India) fueron examinados en ambos lados para el tipo y posición del pterion. Se observaron cuatro tipos de formación. Esfenoparietal en el $89 \%$ de las muestras, fronto temporal en el 7\% de las muestras, estrelladas en $4 \%$ y epiptérico en el 12\% de los casos. Desde la sutura frontocigomática el pterion se encontraba a $3,1 \pm 0,44 \mathrm{~cm}$ en el lado derecho, $3,4 \pm 0,40 \mathrm{~cm}$ en el lado izquierdo y desde el centro del hueso cigomático a 4,1 $\pm 0,45 \mathrm{~cm}$ en el lado derecho y $4,4 \pm 0,32 \mathrm{~cm}$ en el lado izquierdo. Estas variaciones en la morfología de la sutura son comparables a otras poblaciones. Su posición es de interés para los antropólogos, patólogos forenses y cirujanos, y merece una mayor investigación en poblaciones de diferentes regiones.

PALABRAS CLAVE: Pterion; Esfenoides; Craniométrico; Sutural.

\section{REFERENCES}

Agarwal, A. K.; Singh, P. J.; Gupta, S. C. \& Gupta, C. D. Pterion formation and its variation in the skulls of Northern India. Anthropol. Anz., 38:265-9, 1980.

Ahuja, U. K.; Mukerjee, R. N. \& Singh, B. Pterion-Its formation and variation. J. Anat. Soc. Ind., 20(2):103-11, 1971.

Ashley-Montagu, M. F. The anthropological significance of the pterion in the primates. Am. J. Phys. Anthropol., 18(2):159$336,1933$.

Broca, P. Instructions craniologiques et craniométriques. Mém. Soc. Anthrop. Paris, 2:1-203, 1875.

Ersoy, M.; Evliyaoglu, C.; Bozkurt, M. C.; Konuskan, B.; Tekdemir, I. \& Keskil, I. S. Epipteric bones in the pterion may be a surgical pitfall. Minim. Invasive Neurosurg., 46(6):363-5, 2003.

Escosa-Bagé, M.; Sola, R. G.; Liberal-González, R.; Caniego, J. L. \& Castrillo-Cazón, C. Fusiform aneurysm of the middle cerebral artery. Rev. Neurol., 34(7):655-8, 2002.

Lama, M. \& Mottolese, C. Middle meningeal artery aneurysm associated with meningioma. J. Neurosurg. Sci., 44(1):39$41,2000$.

Lee, U. Y.; Park, D. K.; Kwon, S. O.; Paik, D. J. \& Han, S. H. Morphological analysis of pterion in Korea. Korean J. Phys. Anthropol., 14(4):281-9, 2001.

Lindsay, K. W.; Bone, I. \& Callander, R. Neurology and Neurosurgery Illustrated. $2^{\text {nd }}$ ed. New York, Churchill Livingstone, 1991. pp.312-4.

Lovejoy, C. O.; Meindl, R. S.; Mensforth, R. P. \& Barton, T. J. Multifactorial determination of skeletal age at death: a method and blind tests of its accuracy. Am. J. Phys. Anthropol., 68(1):1-14,1985.

Manjunath, K. Y. \& Thomas, I. M. Pterion variants and epipteric ossicles in South Indian skulls. J. Anat. Soc. India, 42:8594, 1993.

Matsumara, G.; Kida, K.; Ichikawa, R. \& Kodama, G. Pterion and epipteric bones in Japanese adults and fetuses, with special reference to their formation and variations. Kaibogaku Zasshi, 66(5):462-71, 1991.

Moore, K. L. \& Dalley, A. F. Clinically Oriented Anatomy. $4^{\text {th }}$ ed. Baltimore, Lippincott Williams and Wilkins, 1999. pp.836-42.

Morales, A. R.; Elizondo, O. R. E. \& Guzman, L. S. Estudio morfológico del pterion y asterion en cráneos adultos mexicanos. Rev. Arg. Anat. Clin., 3(3):77-83, 2011.

Murphy, T. The pterion in the Australian aborigine. Am. J. Phys. Anthropol., 14(2):225-44, 1956.

Mwachaka, P. M.; Hassanali, J. \& Odula, P. Sutural morphology of the pterion and asterion among adult kenyans. J. Morphol. Sci., 26(1):4-7, 2009.

Natekar, P. E.; DeSouza, F. M. \& Natekar, S. P. Pterion: An anatomical variation and surgical landmark. Indian J. Otol., 17(2):83-5, 2011.

Oguz, O.; Sanli, S. G.; Bozkir, M. G. \& Soames, R. W. The pterion in Turkish male skulls. Surg. Radiol. Anat., 26(3):220-4, 2004.

Saxena, S. K.; Jain, S. P. \& Chowdhary, D. S. A comparative study of pterion formation and its variations in the skulls of Nigerians and Indians. Anthropol. Anz., 46(1):75-82, 1988. 
Saxena, R. C.; Bilodi, A. K.; Mane, S. S. \& Kumar, A. Study of pterion in skulls of Awadh area--in and around Lucknow. Kathmandu Univ. Med. J. (KUMJ), 1(1):32-3, 2003.

Singh, R. Incidence of sutural bones at asterion in adults indians skulls. Int. J. Morphol., 30(3):1182-6, 2012.

Specktor, S.; Valarezo, J.; Fliss, D. M.; Gil, Z.; Cohen, J.; Goldman, J. \& Umansky, F. Olfactory groove meningiomas from neurosurgical and ear, nose, and throat perspectives: approaches, techniques, and outcomes. Neurosurgery, 57/4 Suppl.):268-80, 2005.

Urzi, F.; Iannello, A.; Torrisi, A.; Foti, P.; Mortellaro, N. F. \& Cavallaro, M. Morphological variability of pterion in the human skull. Ital. J. Anat. Embryol., 108(2):83-117, 2003.

Wang, Q.; Opperman, L. A.; Havil, L. M.; Carlson, D. S. \& Dechow, P. C. Inheritance of sutural pattern at the pterion in Rhesus monkey skulls. Anat. Rec. A Discov. Mol. Cell Evol. Biol., 288(10):1042-9, 2006.

Williams, L. P.; Bannister, L. H.; Berry, M. M.; Collins, P.; Dyson, M.; Dussek, J. E. \& Ferguson, M. W. J. Gray's Anatomy. 38 ${ }^{\text {th }}$ ed. London, Churchill Livingstone, 1995. pp.568-95.

Zalawadia, A.; Vadgama, J.; Ruparelia, S.; Patel, S.; Rathod, S. P. \& Patel, S. V. Morphometric study of pterion in dry skull of Gujurat Region. Natl. J. Integrated Res. Med., 1(4):25-9, 2010.

\author{
Correspondence to: \\ Dr. Seema \\ Professor \\ Department of Anatomy \\ SriGuruRam Das Institute of Medical Sciences and Research \\ Vallah (Amritsar) (Punjab) \\ INDIA
}

Email: drseema16@gmail.com

Received: 26-05-2014

Accepted: 22-09-2014 